\title{
Changing spatial distribution of fish stocks in relation to climate and population size on the Northeast United States continental shelf
}

\author{
Janet A. Nye ${ }^{1, *}$, Jason S. Link ${ }^{1}$, Jonathan A. Hare ${ }^{2}$, William J. Overholtz ${ }^{1}$ \\ ${ }^{1}$ National Marine Fisheries Service, Northeast Fisheries Science Center, Woods Hole Laboratory, 166 Water St., Woods Hole, \\ Massachusetts 02543, USA \\ ${ }^{2}$ National Marine Fisheries Service, Northeast Fisheries Science Center, Narragansett Laboratory, 28 Tarzwell Drive, \\ Narragansett, Rhode Island 02882, USA
}

\begin{abstract}
We tested the hypothesis that recent oceanographic changes associated with climate change in the Northeast United States continental shelf ecosystem have caused a change in spatial distribution of marine fish. To do this, we analyzed temporal trends from 1968 to 2007 in the mean center of biomass, mean depth, mean temperature of occurrence, and area occupied in each of 36 fish stocks. Temporal trends in distribution were compared to time series of both local- and large-scale environmental variables, as well as estimates of survey abundance. Many stocks spanning several taxonomic groups, life-history strategies, and rates of fishing exhibited a poleward shift in their center of biomass, most with a simultaneous increase in depth, and a few with a concomitant expansion of their northern range. However, distributional changes were highly dependent on the biogeography of each species. Stocks located in the southern extent of the survey area exhibited much greater poleward shifts in center of biomass and some occupied habitats at increasingly greater depths. In contrast, minimal changes in the center of biomass were observed in stocks with distributions limited to the Gulf of Maine, but mean depth of these stocks increased while stock size decreased. Largescale temperature increase and changes in circulation, represented by the Atlantic Multidecadal Oscillation, was the most important factor associated with shifts in the mean center of biomass. Stock size was more often correlated with the total area occupied by each species. These changes in spatial distribution of fish stocks are likely to persist such that stock structure should be re-evaluated for some species.
\end{abstract}

KEY WORDS: Atlantic Multidecadal Oscillation • Climate change - Biogeography · Center of biomass · Northeast United States continental shelf · Distribution · Area-abundance relationships

Resale or republication not permitted without written consent of the publisher

\section{INTRODUCTION}

Recently water temperatures have increased both globally (Levitus et al. 2000, Knutson et al. 2006, Lozier et al. 2008) and regionally (e.g. in the Northwest Atlantic) (Friedland \& Hare 2007, Belkin 2009). Climate models indicate that this warming trend is likely to continue (IPCC 2007, Solomon et al. 2009). Many recent studies have detected ecological impacts of climate change (Walther et al. 2002, Parmesan \& Yohe 2003, Rosenzweig et al. 2008), but in many situations it remains difficult to disentangle the effects of climate change with those of other anthropogenic influences. This fact is especially true of exploited species that may exhibit responses consistent with both climateinduced and harvest-induced impacts. Modeling studies suggest that both exploitation and climate change will affect the dynamics of exploited species (Clark et al. 2003, Fogarty et al. 2007, Hare et al. in press), and, for successful management, it is important to document the relative importance and synergistic effects of these 2 stressors.

The first-order response of organisms to climate change is a shift in distribution (Frank et al. 1990, 
Shuter \& Post 1990, McCarty 2001), which, in marine species, may be manifested as a change in the center of biomass, an expansion or contraction of the species' range, or a change in depth distribution. These responses have recently been documented for fish communities in the North Sea (Perry et al. 2005) and in the Bering Sea (Mueter \& Litzow 2008). Reponses of marine fishes consistent with warming water bodies would be a poleward shift in the mean center of biomass and an increase in the mean depth of occurrence. The ranges of 'cold' species may be reduced by warming waters, while 'warm' species might expand their range.

The potential importance of temperature regime and climate on fish stocks, especially those that are economically important, has been studied on relatively short temporal and spatial scales in the NW Atlantic (Frank et al. 1990, Murawski 1993, Drinkwater et al. 2003, Hare \& Able 2007). Frank et al. (1990) hypothesized that distributional changes in response to warming would be most pronounced in Canadian fish stocks at the southern extent of their range, based on historical reports of distributional changes due to warming in the 1950s (Taylor et al. 1957). Murawski (1993) classified species into groups that would be more or less likely to exhibit changes in distribution in a warmer climate based on temperature preferences and historical distribution. Similarly, Rose (2005) predicted that, with warming, American shad, alewife, Atlantic mackerel, American plaice, and winter flounder, among other species, would shift their distribution north. Drinkwater (2005) predicted that the George's Bank and Gulf of Maine stocks of Atlantic cod Gadus morhua would decline in abundance and move poleward.

Since these studies, the Northeast United States continental shelf ecosystem has experienced a consistently warm period in the last $10 \mathrm{yr}$ and a rebuilding of many overfished stocks, presenting an opportunity to reexamine the links between distribution, warming, and population abundance. The purpose of the present study was to quantify the relationship between the spatial distribution of 36 NE United States fish stocks and the changes in temperature regime and abundance using a $40 \mathrm{yr}$ trawl survey time series (1968 to 2007). We hypothesize that rising water temperatures would induce at least one of the following responses: a poleward shift in the center of biomass, an increase in the mean depth of occurrence, a range expansion or contraction depending upon biogeography of the species, or no distributional shift consistent with warming, but an increase in the mean temperature of occurrence. We also hypothesize that these responses would be mediated by changes in the abundance of each stock, many of which have occurred over the time period examined.

\section{MATERIALS AND METHODS}

Fish data. Abundance and distribution data for 36 fish stocks were obtained from the Northeast Fisheries Science Center (NEFSC) spring trawl survey, which has been carried out on the NE United States continental shelf since 1968 (Fig. 1). The data collection and sample processing methods have been described by Azarovitz (1981). Briefly, the survey employs a stratified random design, with stations allocated proportionally to stratum area. A $12 \mathrm{~mm}$ mesh codend liner is used to retain smaller bodied and juvenile fish. All fish for each species were counted and weighed. Correction factors were applied for changes in vessels, gear, and doors when appropriate. Only tows in which there were no gear or duration problems from offshore trawl survey strata consistently sampled over the spring survey time series (Strata 01010-01300, 01360-01400, 01610-01760) were used in statistical analysis. The strata used are shown in Fig. 1. There has been no significant change in the timing of the spring survey, and the mean annual latitude and longitude of the stations has not changed over time, using the strata that were consistently sampled over the duration of this $40 \mathrm{yr}$ time series.

We chose 36 stocks for investigation, because individuals from these stocks were caught every year during the spring survey, were consistently caught in relatively high numbers, and represented a wide range of taxonomic groups (Table 1, for species' scientific

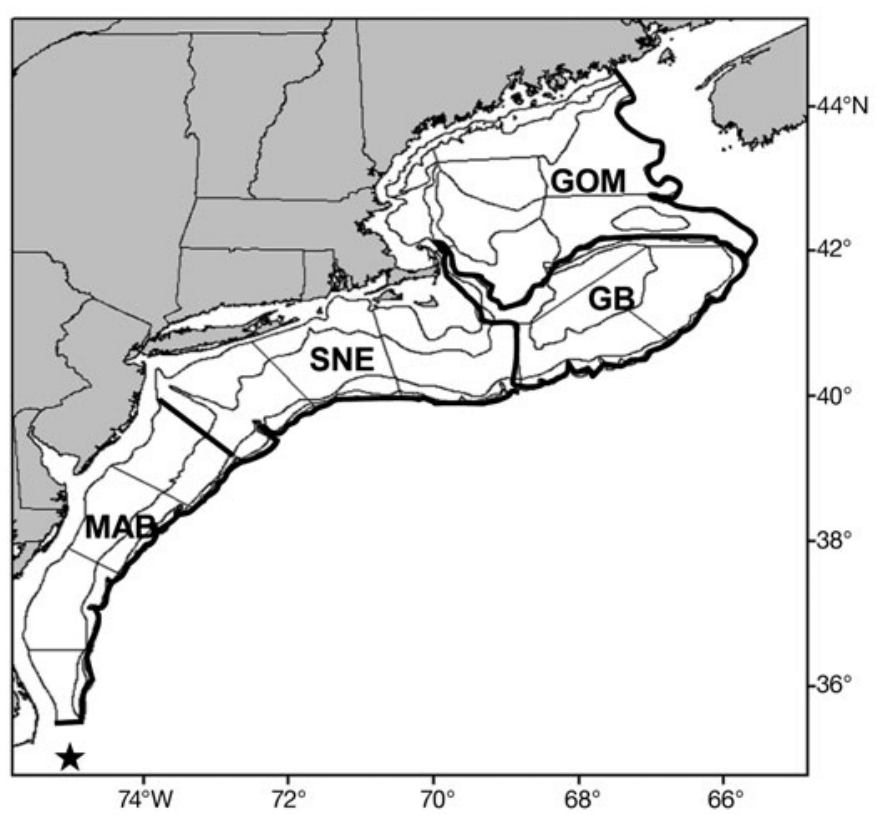

Fig. 1. Survey area with strata used in this analysis. GOM: Gulf of Maine; GB: George's Bank; SNE: Southern New England; MAB: mid-Atlantic Bight; $\star$ : fixed point used to calculate distance, $d$, in each year 
Table 1. Northeast USA fish stocks analyzed in the present study with scientific name, family, habitat (P: pelagic; D: demersal), species historical range, and ecoregion by which stocks were separated for this study (N: northern; S: southern). Species are ordered by taxonomy from most to least ancestral

\begin{tabular}{|c|c|c|c|c|c|}
\hline Species & Scientific name & Family & Habitat & Species historical range & Ecoregion \\
\hline Spiny dogfish & Squalus acanthias & Squalidae & $\mathrm{D}$ & Greenland to Argentina & $\mathrm{S}$ \\
\hline Little skate & Leucoraga erinacea & Rajidae & $\mathrm{D}$ & Newfoundland to North Carolina & $\mathrm{S}$ \\
\hline Thorny skate & Amblyraja radiata & Rajidae & $\mathrm{D}$ & Greenland to New York & $\mathrm{N}$ \\
\hline Winter skate & Leucoraja ocellata & Rajidae & $\mathrm{D}$ & Newfoundland to North Carolina & $\mathrm{S}$ \\
\hline Alewife & Alosa pseudoharengus & Clupeidae & $\mathrm{P}$ & Labrador to South Carolina & $\mathrm{S}$ \\
\hline American shad & Alosa sapidissima & Clupeidae & $\mathrm{P}$ & Labrador to Florida & $\mathrm{S}$ \\
\hline Atlantic herring & Clupea harengus & Clupeidae & $\mathrm{P}$ & Greenland to South Carolina & $\mathrm{S}$ \\
\hline Atlantic cod & Gadus morhua & Gadidae & $\mathrm{D}$ & Greenland to North Carolina & $N \& S$ \\
\hline Haddock & Melanogrammus aeglefinus & Gadidae & $\mathrm{D}$ & New Jersey to Newfoundland & $N \& S$ \\
\hline Pollock & Pollachius virens & Gadidae & $\mathrm{P}$ & Greenland to North Carolina & $\mathrm{N}$ \\
\hline Silver hake & Merluccius bilinearis & Gadidae & $\mathrm{P}$ & Newfoundland to South Carolina & $N \& S$ \\
\hline Red hake & Urophycis chuss & Merlucidae & $\mathrm{D}$ & Newfoundland to North Carolina & $N \& S$ \\
\hline Spotted hake & Urophycis regia & Merlucidae & $\mathrm{D}$ & Maine to Gulf of Mexico & $\mathrm{S}$ \\
\hline White hake & Urophycis tenuis & Merlucidae & $\mathrm{D}$ & Newfoundland to North Carolina & $\mathrm{N}$ \\
\hline Cusk & Brosme brosme & Lotidae & $\mathrm{D}$ & Newfoundland to New Jersey & $\mathrm{N}$ \\
\hline Goosefish & Lophius americanus & Lophiidae & $\mathrm{D}$ & Newfoundland to North Carolina & $\mathrm{S}$ \\
\hline American plaice & Hippoglossoides platessoides & Pleuronectidae & $\mathrm{D}$ & Labrador to Rhode Island & $\mathrm{N}$ \\
\hline Atlantic halibut & Hippoglossus hippoglossus & Pleuronectidae & $\mathrm{D}$ & Labrador to Virginia & $\mathrm{N}$ \\
\hline Yellowtail flounder & Limanda ferruginea & Pleuronectidae & $\mathrm{D}$ & Labrador to Virginia & $N \& S$ \\
\hline Winter flounder & Pseudopleuronectes americanus & Pleuronectidae & $\mathrm{D}$ & Labrador to Virginia & $N \& S$ \\
\hline Fourspot flounder & Paralichthys oblongus & Paralichthyidae & $\mathrm{D}$ & George's Bank to Florida & $\mathrm{S}$ \\
\hline Summer flounder & Paralichthys dentatus & Paralichthyidae & $D$ & Massachusetts to South Carolina & $\mathrm{S}$ \\
\hline Windowpane flounder & Scophthalmus aquosus & Scophthalmidae & e D & Newfoundland to Florida & $\mathrm{S}$ \\
\hline Atlantic mackerel & Scomber scombrus & Scombridae & $\mathrm{P}$ & Labrador to North Carolina & $\mathrm{S}$ \\
\hline Ocean pout & Zoarces americanus & Zoarcidae & $\mathrm{D}$ & Labrador to Delaware & $\mathrm{S}$ \\
\hline Atlantic wolffish & Anarhichas lupus & Anarhichadidae & e D & Greenland to New Jersey & $\mathrm{N}$ \\
\hline Blackbelly rosefish & Helicolenus dactylopterus & Scorpaenidae & $\mathrm{D}$ & Nova Scotia to Venezuela & $\mathrm{S}$ \\
\hline Longhorn sculpin & Myoxocephalus octodecemspinosus & Cottidae & $\mathrm{D}$ & Newfoundland to Virginia & $\mathrm{S}$ \\
\hline Sea raven & Hemitripterus americanus & Hemitripteridae & e D & Labrador to Virginia & $\mathrm{S}$ \\
\hline Acadian redfish & Sebastes fasciatus & Sebastidae & $\mathrm{D}$ & Massachusetts to Newfoundland & $\mathrm{N}$ \\
\hline
\end{tabular}

names please refer to this table throughout). Most species included here have only 1 identified stock in the region, and were analyzed as such. Those species with multiple stocks were analyzed by ecoregions, which roughly correspond to stock boundaries. The 2 ecoregions were the Gulf of Maine (GOM, 'northern') and combined areas of George's Bank, southern New England, and mid-Atlantic Bight (GB, SNE, and MAB areas, respectively, 'southern'). Red hake, silver hake, yellowtail flounder, winter flounder, Atlantic cod, and haddock were analyzed by ecoregion. Additionally, species limited to the GOM were considered coolwater species for the study area and were classified as 'northern' species, while those species that were limited to $\mathrm{GB}, \mathrm{SNE}$, and $\mathrm{MAB}$ or that spanned the entire range of the study area were classified as 'southern' species for ecoregion comparisons.

Spatial metrics. To examine the relationship between changes in distribution and climate conditions, 6 distributional parameters were calculated: center of biomass, maximum latitude, minimum latitude, mean depth of occurence, mean temperature of occurence, and area occupied. Center of biomass was calculated in 4 steps. (1) Station latitude and longitude were converted to across-shelf and along-shelf distances from the $200 \mathrm{~m}$ isobath and Cape Hatteras, North Carolina, in Matlab 7.7 (The Mathworks 2008). This transformation was needed since the survey follows the curvilinear shelf and straight averages of latitude and longitude can result in centers of biomass off the shelf and outside of the survey area. (2) Biomass-weighted mean along-shelf and across-shelf location was calculated using:

$$
X_{j}=\frac{\sum_{i=1}^{n} w_{i} X_{i j}}{\sum w_{i}}
$$

where $X$ is the parameter of interest (along-shelf location, across-shelf location, temperature, etc.), $j$ is the survey year, $w_{i}$ is the log-transformed biomass [log $(x+1)$ in $\mathrm{kg}$ ] for each station $i$. (3) Biomass-weighted mean values of across-shelf and along-shelf distances 
were then converted back to mean latitude and mean longitude values for analysis. (4) Distance between each center of biomass and a fixed point $\left(35^{\circ} \mathrm{N}\right.$ latitude and $75^{\circ} \mathrm{W}$ longitude) was calculated. This fixed point roughly corresponds to Cape Hatteras, NC, and is below the southernmost extent of the NEFSC trawl survey (Fig. 1). We used the great circle distance formula to calculate the distance $(d)$ :

$$
\begin{aligned}
d= & A \cos [(\sin 35) \times \sin (\text { mlat })]+ \\
& \cos \{35 \times \cos (\text { mlat }) \times \cos [\text { mlon }-(-75)]\}
\end{aligned}
$$

where mlat is the mean latitude and mlon is the mean longitude at the center of biomass. All latitudes and longitudes were converted to radians. The value of $d$, hereafter called distance, was converted to kilometers by assuming the earth is spherical with a radius of $6367 \mathrm{~km}$. Changes in distance incorporate both alongshelf and across-shelf shifts in distribution.

Biomass-weighted mean depth and mean temperature were calculated for each stock using Eq. (1). The parameter of interest $\left(X_{i j}\right)$ was bottom depth or bottom temperature at station $i$ during survey year $j$. The minimum and maximum latitude at which each stock was present in each year was derived from station location data.

Area occupied by each stock in each year was calculated by dividing the survey area into 10-minute spatial cells $\left(261 \mathrm{~km}^{2}\right)$ and then allocating each station to the appropriate cell, similar to the method of Methratta \& Link (2007). The area of grids in which the species was present was summed to represent the total area that the stock occupied. In each year, some 10-minute spatial cells were not sampled so this is a conservative measure of 'area occupied' and an indicator of area relative to the survey time series.

Annual relative abundance and biomass for each species was estimated as the stratified mean numbers and biomass $(\mathrm{kg})$ per tow respectively.

Environmental metrics. Two indices of temperature variability over the ecosystem were used: mean bottom temperatures (BT) during the spring survey and mean annual sea surface temperatures (SST). Mean-stratified annual BT of each survey was estimated from BT measurements taken at each station during the spring survey. Prior to 1990, BTs were measured with water bottles, and, from then on, BTs were measured with conductivity, temperature, and depth profilers (CTDs).

SST on the continental shelf was estimated using the extended reconstructed sea surface temperature dataset (ERSST Version 3, www.ncdc.noaa.gov/oa/climate/ research/sst/ersstv3.php). This dataset is based on the SST compilation of the International Comprehensive Ocean-Atmospheric Data Set and uses interpolation procedures to reconstruct SST in regions with sparse data (Smith \& Reynolds 2004). While the dataset extends back to 1854, we used values from 1968 to 2007, corresponding to the timing of the NEFSC trawl survey where the $95 \%$ confidence interval of the data was $0.1^{\circ} \mathrm{C}$ or less (Smith \& Reynolds 2004). The spatial resolution of the data was $2^{\circ}$ longitude by $2^{\circ}$ latitude, and we used only grids that overlapped spatially with our survey area to calculate the mean annual SST, hereafter simply SST.

Two indices of longer term climatological conditions were also used: the North Atlantic Oscillation (NAO) and Atlantic Multidecadal Oscillation (AMO). The NAO index was calculated as the difference between surface pressure of the subtropical (Azores) high and the subpolar (Iceland) low. The mean winter NAO index was used because most of the variance in the NAO occurs in the winter months and is the only large-scale pressure and circulation pattern that is evident throughout the year in the northern hemisphere (Hurrell et al. 2003). Variability in the NAO has been associated with changes in precipitation, SST, wind fields, sea-ice formation, and, thus, with ecosystem change (Beaugrand et al. 2003, Drinkwater et al. 2003, Greene et al. 2003, Beaugrand 2004) and fish recruitment (O'Brien et al. 2000, Reid et al. 2001, Lindley et al. 2003).

The AMO is a 65 to 80 yr cycle in the North Atlantic thought to be driven by ocean thermohaline circulation (Sutton \& Hodson 2005). The AMO is based on the detrended Kaplan SST dataset $\left(5^{\circ}\right.$ latitude $\times 5^{\circ}$ longitude grids) from 0 to $70^{\circ} \mathrm{N}$. The linear effects of anthropogenic climate change are removed to represent the natural variation in SSTs that has been observed over the last $150 \mathrm{yr}$ and has been correlated with natural fluctuations over the last millennium (Gray et al. 2004, Sutton \& Hodson 2005). The AMO is driven by thermohaline circulation and is associated with warmer land and ocean temperatures, decreases in summer precipitation, and increases in the number of droughts (Sutton \& Hodson 2007). In the United States, the area relevant to the present study, these climate effects are most pronounced in the summer and somewhat less prominent in the autumn and winter at lower latitudes (Sutton \& Hodson 2007).

Analysis. To statistically test for changes in spatial distribution measures over time we conducted linear regressions incorporating the appropriate temporal autocorrelation into the error structure for each stock (Proc Autoreg, SAS Institute, v9.1.3). We calculated a separate linear regression over time for each stock and for each distributional measure: mean distance, minimum latitude, maximum latitude, mean depth of occurrence, mean temperature of occurrence, and area occupied. A change in mean distance represents a shift in the center of biomass and is the strongest indicator of distributional shifts. Minimum and maximum lati- 
tude were also used as indictors of distributional shifts. While the center of biomass for a species may shift due to spatial differences in biomass, minimum and maximum latitude were determined only by presence, i.e. a change in minimum or maximum latitude over time may indicate the recent occurrence of a stock outside its previous range or the local extirpation at the edge of a stock's range.

Additionally, maximum and minimum latitude can be used in conjunction with area occupied to determine range contraction or expansion. Evidence of range expansion includes a statistically significant increase in area occupied, an increase in maximum latitude, and/or a decrease in minimum latitude. Evidence of range contraction includes a statistically significant decrease in the area occupied, a decrease in maximum latitude, and/or an increase in minimum latitude. We examined the relationship between area occupied and abundance (log-transformed number of individuals) for each stock using a power function to understand the effects of changes in abundance on spatial distribution.

ArcGIS software was used to create smoothed maps in $5 \mathrm{yr}$ time blocks of several representative species using the inverse distance weighting (IDW) method. For each species, raster size was maintained at a constant level and the smoothing power, $p$, was equal to 2 . The spatial pattern of mean annual BT for each $5 \mathrm{yr}$ time block was also depicted using IDW in ArcGIS. In this analysis we used inshore and offshore strata to visualize spatial trends.

Because there are many possible distributional responses of fishes to changes in both temperature regime and population abundance, we used canonical correlation analysis (CanCorr) to examine the linear relationship between these multiple response variables and multiple explanatory variables in each stock (Proc Cancorr, SAS Institute). CanCorr is a multivariate generalization of correlation analysis that relates 2 sets of multiple variables. A pair of canonical variates is generated from each set of original variables, where each canonical variate is a linear combination of the original variables. The explanatory and response variables, and their abbrevations, are given in Table 2 .

To evaluate the effect of biogeography on distributional responses, stocks were classified as either 'northern' or 'southern' depending on their range. Stocks restricted to the GOM area and north were classified as 'northern' stocks and stocks whose ranges extended south of the GOM were classified as 'southern' (Table 1). The slopes from the linear regressions of distributional metrics and time were compared between the 2 classifications using a Mann-Whitney $U$-test. Histograms of the slopes of the linear regressions were compared for each of 6 distributional metrics.
Table 2. Explanatory and response variables used in statistical analyses with corresponding abbreviations

\begin{tabular}{|lc|}
\hline Variables & Abbreviation \\
\hline Explanatory & \\
Bottom temperature & BT \\
Extended reconstructed sea surface & SST \\
temperature & \\
Atlantic Multidecadal Oscillation & AMO \\
North Atlantic Oscillation & NAO \\
Relative biomass & BIOMASS \\
& \\
Response & \\
Distance the mean center of biomass & distance \\
shifted poleward & \\
Minimum latitude & minlat \\
Maximum latitude & maxlat \\
Mean depth of occurrence & depth \\
Mean temperature of occurrence & temp \\
Relative area of occupation & area \\
\hline
\end{tabular}

\section{RESULTS}

\section{Environmental metrics}

Several metrics indicate a recent warming trend on the NE United States continental shelf (Figs. 2 \& 3). The spatial distribution of BTs taken from the trawl survey indicates that, over the last $40 \mathrm{yr}$, the coolest time period occurred at the beginning of the survey, from 1968 to 1972 (Fig. 2). Temperatures were the warmest from 1973 to 1977 and then from 1998 to 2002. The spatial patterns of BTs reflect the temporal trends in both BTs and SSTs; temperatures have been consistently warm since the late 1990s, except in the cool years from 2003 to 2005 (Fig. 3a,b). SST anomalies have been positive for the past $10 \mathrm{yr}$ (Fig. 3b). Trends in the winter NAO index are more variable, but, for the past $10 \mathrm{yr}$, have been closer to the long-term mean (Fig. 3c). AMO anomalies, on the other hand, have been increasing steadily since the earlier 1970s, indicating changes in circulation patterns and a general warming over the entire North Atlantic, a spatial and temporal scale that is larger than the NE United States shelf, the scale to which BT and SST correspond.

\section{Distributional metrics}

There were clear poleward shifts consistent with warming in many fish stocks of the NE United States, most notably for alewife, American shad, silver hakesouthern, red hake-southern, and yellowtail floundersouthern (Fig. 4). Linear regressions of the annual center of biomass indicated a statistically significant pole- 

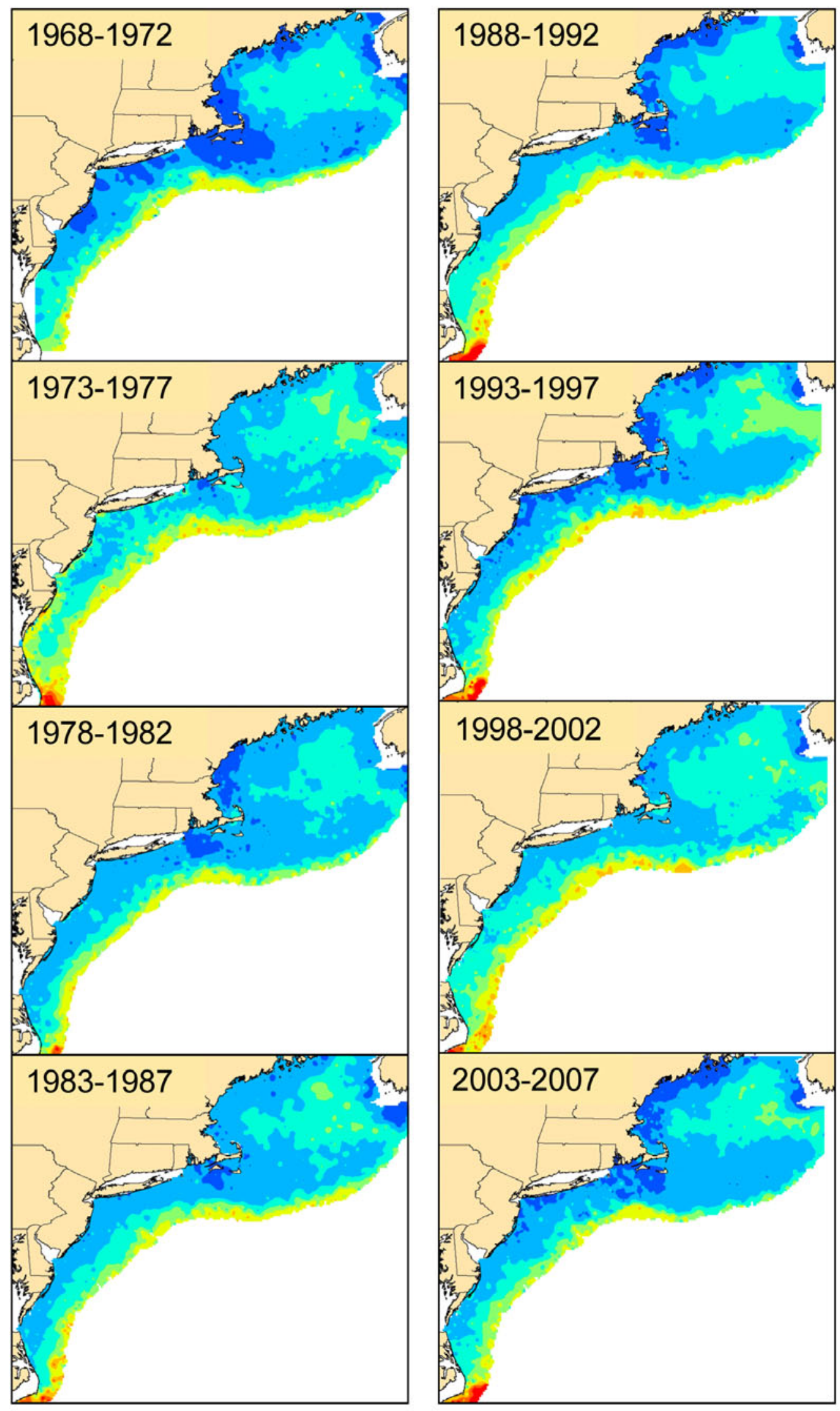

\section{Temperature ( $\left.{ }^{\circ} \mathrm{C}\right)$

\begin{tabular}{|l|}
\hline $0-2$ \\
\hline $2.1-4$ \\
$4.1-6$ \\
$6.1-8$ \\
\hline$\quad 8.1-10$ \\
\hline $10.1-12$ \\
\hline $12.1-14$ \\
$14.1-16$ \\
$>16$
\end{tabular}

Fig. 2. Spatial representation of bottom temperatures taken during the Northeast Fisheries Science Center (NEFSC) surveys in 5 yr time blocks 

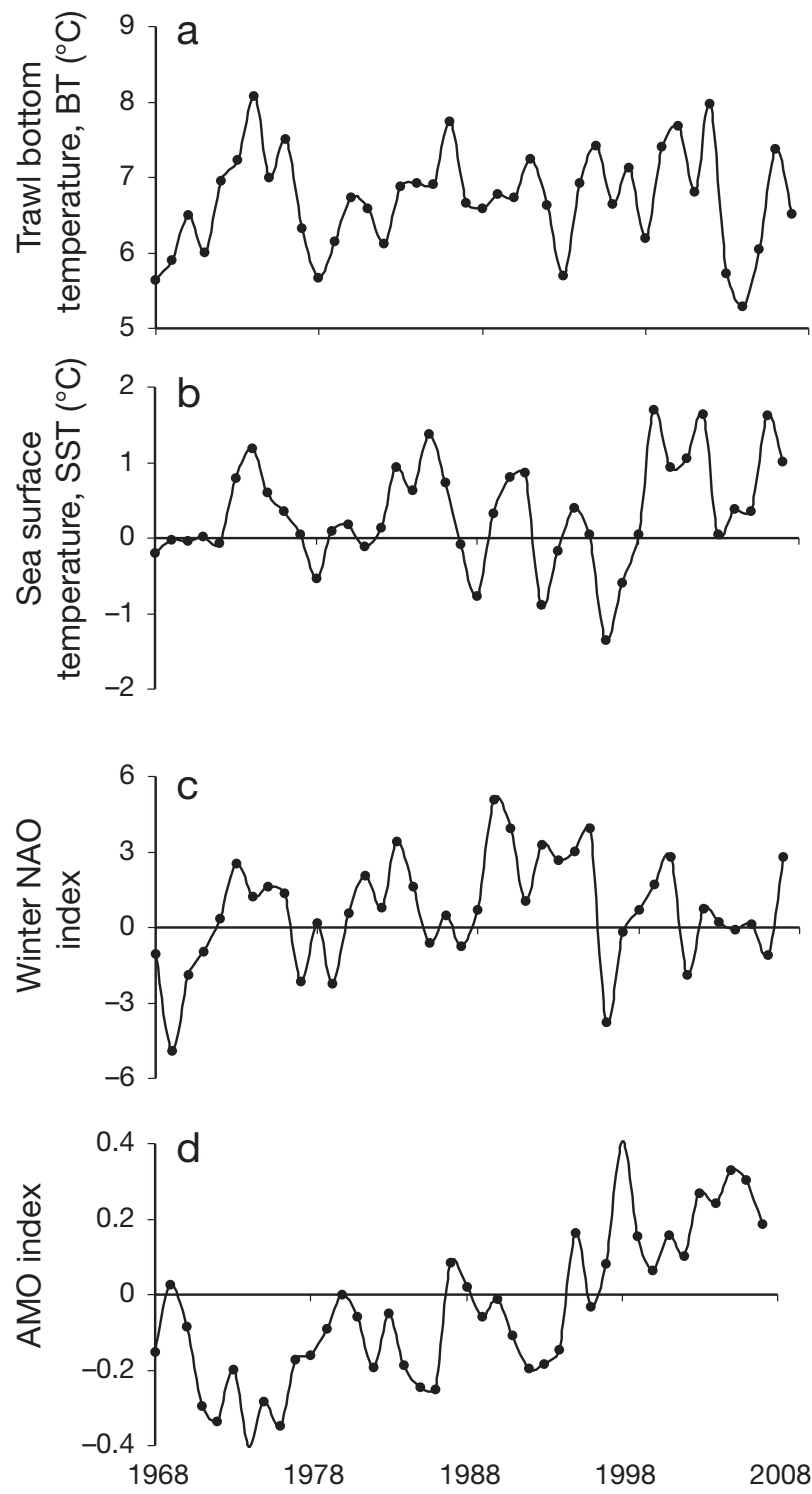

Fig. 3. Time series of environmental variables representing the temperature and climatological trends for the area of the Northeast Fisheries Science Center (NEFSC) survey that we examined. Trends in temperature regime are represented by (a) mean annual bottom temperatures taken during the NEFSC trawl survey and (b) standardized mean sea surface temperature for the area of the bottom trawl survey. Large-scale climatological trends are represented by the (c) standardized winter NAO (North Atlantic Oscillation) index and (d) standardized AMO (Atlantic Multidecadal Oscillation) index

ward shift in 17 of the 36 stocks, including a broad range of taxa and life histories (Table 3 ). The center of biomass for 4 species appeared to shift southward, which would be inconsistent with a response to warming. These species included 2 elasmobranchs (winter skate and little skate) and 2 stocks found primarily in the GOM (Atlantic cod-GOM and winter floundernorthern).
A statistically significant increase in the area occupied, indicative of a range expansion, was found for 10 stocks (Table 3 ). In addition, decreases in minimum latitude and increases in maximum latitude, which are also indicative of range expansion, were found in 1 and 5 stocks, respectively. Strong evidence of range expansion includes a statistically significant increase in maximum latitude and a decrease in minimum latitude, in addition to an increase in area occupied. American shad and spotted hake fit all 3 criteria. The range expansions (area occupied) of the largest magnitude occurred in Atlantic herring and spotted hake and correspond to increases of roughly 34000 and $20000 \mathrm{~km}^{2}$, respectively, over the $40 \mathrm{yr}$ time series.

Twelve species experienced range contraction, the largest of which occurred in thorny skate, Atlantic cod-GB, and yellowtail flounder-southern (Table 3). The magnitude of these range contractions corresponds to a reduction in the area occupied by these stocks of from 18000 to $21000 \mathrm{~km}^{2}$ over the $40 \mathrm{yr}$ time period. All stocks exhibiting a significant range contraction were northern species at the southern extent of their range. Strong evidence of range contraction includes statistically significant decreases in the area occupied, a decrease in maximum latitude, and an increase in minimum latitude. Atlantic cod-GB, Acadian redfish, Atlantic wolffish, and cusk fit these criteria (Table 3). Six stocks exhibited range contraction, as well as poleward movement, and, again, all of these stocks were northern species at the southern extent of their range.

Changes in minimum and maximum latitude corroborate the changes in area occupied and poleward movement in most stocks, but also reveal more subtle changes in spatial distribution of other stocks. Although there was no change in the center of biomass or area occupied for summer flounder, fourspot flounder, and sea raven, shifts in their distribution may have occurred, as indicated by changes in minimum and maximum latitude. The maximum latitude of summer flounder and fourspot flounder has shifted poleward, suggesting a poleward movement and/or range expansion. The minimum latitude of sea raven has increased, suggesting a poleward movement or range contraction of this species.

Statistically significant increases in mean depth of occurrence were detected for 17 stocks (Table 3); 8 of these stocks also exhibited poleward shifts in distribution (Table 3, Fig. S1 in the Electronic Supplement, available at www.int-res.com/articles/suppl/m393p111_ app.pdf). Five stocks exhibited no significant change in the center of biomass, while winter skate and Atlantic cod-GOM appear to have shifted their biomass to greater depths, while moving away from the poles. Thorny skate, pollock, cusk, and Atlantic wolffish were 


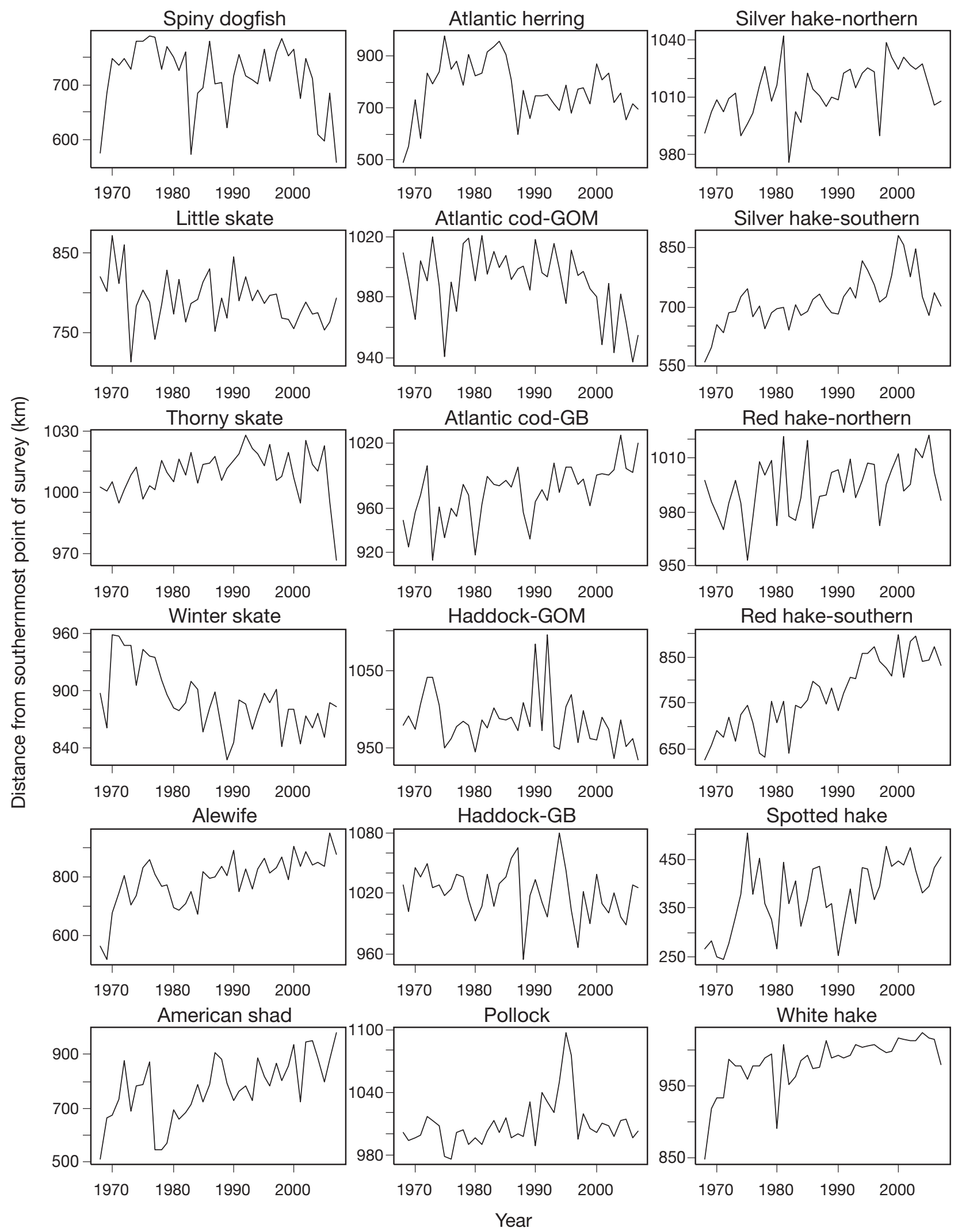

Fig. 4. Time series of the mean center of biomass in 36 stocks caught during the Northeast Fisheries Science Center (NEFSC) spring multispecies survey. Mean center of biomass is measured as the distance from the southernmost point of the survey 

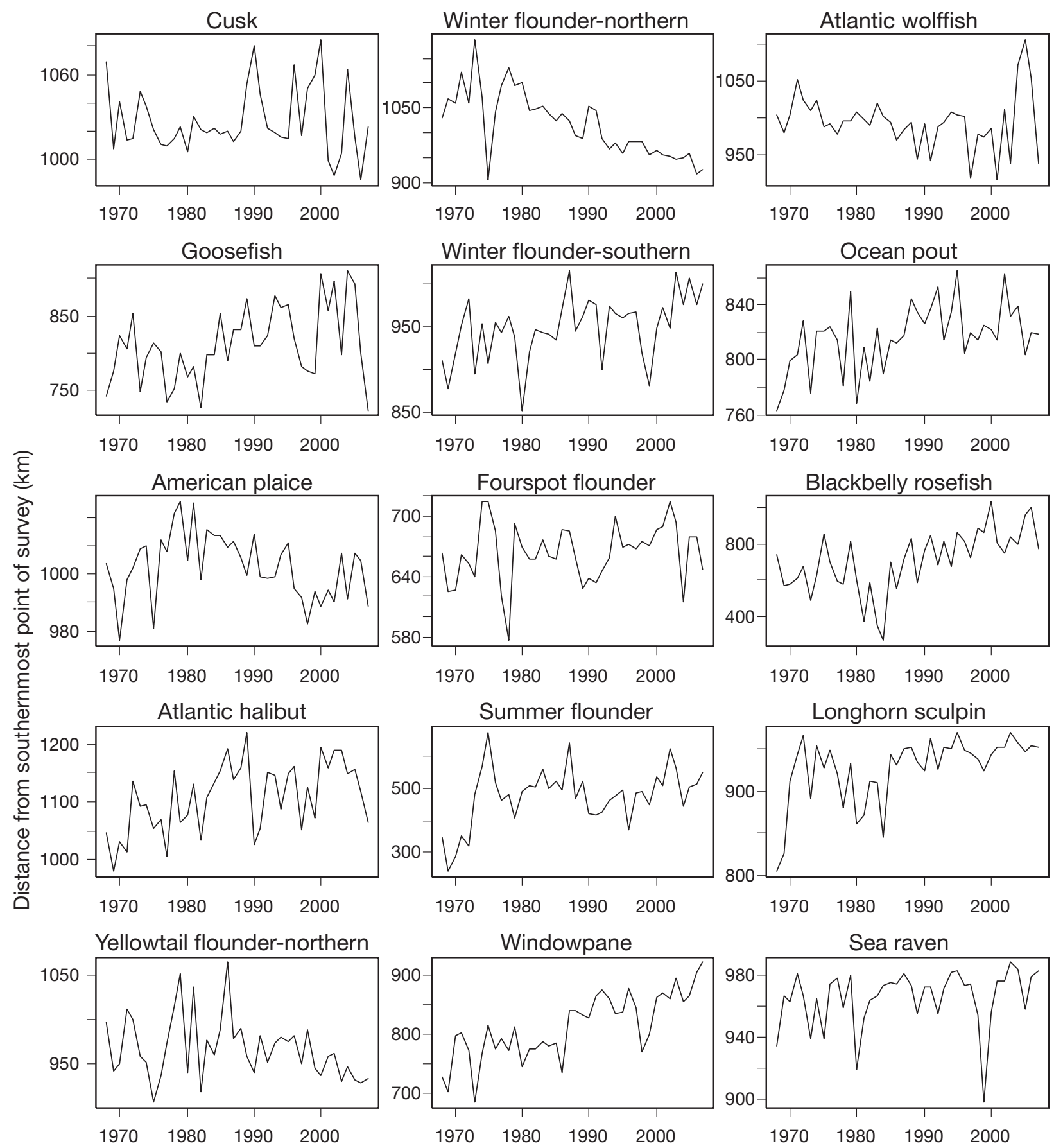

Winter flounder-southern
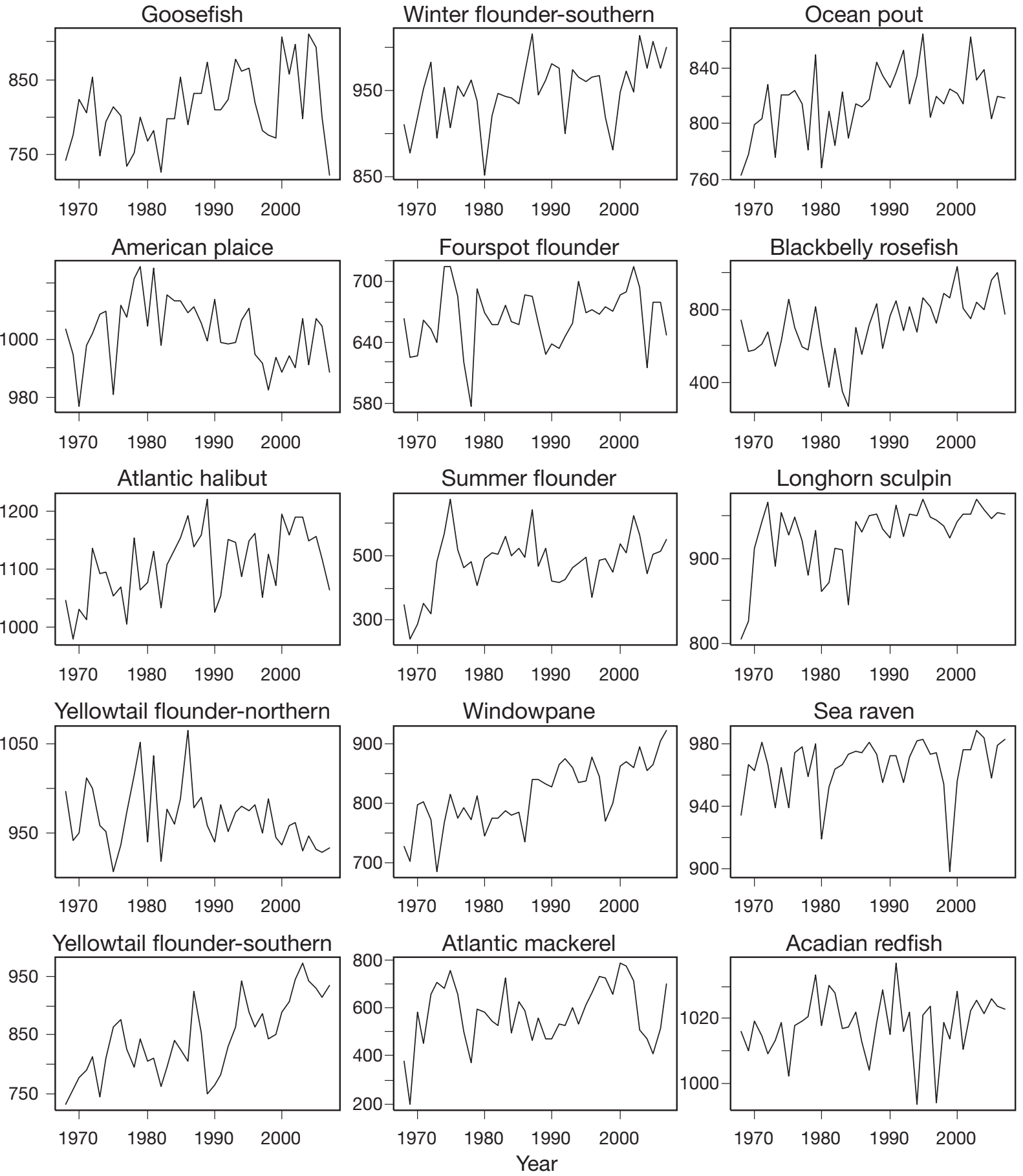

Fig. 4 (continued) 
Table 3. Summary of trends in time series of distributional responses for 36 stocks on the Northeast United States continental shelf. Only statistically significant $(\mathrm{p}<0.05)$ slopes are reported. Significant slopes were not detected in any metrics for spiny dogfish and haddock-GOM. GOM: Gulf of Maine; GB: George's Bank

\begin{tabular}{|c|c|c|c|c|c|c|}
\hline Stock & $\begin{array}{c}\text { Poleward } \\
\text { movement } \\
\left(\mathrm{km} \mathrm{yr}^{-1}\right)\end{array}$ & $\begin{array}{c}\text { Area } \\
\text { occupied } \\
\left(\mathrm{km}^{2} \mathrm{yr}^{-1}\right)\end{array}$ & $\begin{array}{l}\text { Maximum } \\
\text { latitude } \\
\left({ }^{\circ} \text { lat } \mathrm{yr}^{-1}\right)\end{array}$ & $\begin{array}{l}\text { Minimum } \\
\text { latitude } \\
\left({ }^{\circ} \text { lat } \mathrm{yr}^{-1}\right)\end{array}$ & $\begin{array}{c}\text { Mean } \\
\text { temperature } \\
\left({ }^{\circ} \mathrm{C} \mathrm{yr}^{-1}\right)\end{array}$ & $\begin{array}{c}\text { Mean } \\
\text { depth } \\
\left(\mathrm{m} \mathrm{yr}^{-1}\right)\end{array}$ \\
\hline \multicolumn{7}{|l|}{ Spiny dogfish } \\
\hline Winter skate & -1.35 & 287.4 & & -0.066 & & 0.78 \\
\hline Little skate & -0.83 & & & & & \\
\hline Thorny skate & & -517.5 & -0.012 & & & 0.48 \\
\hline Atlantic herring & & 868.6 & & & 0.031 & \\
\hline Alewife & 5.47 & 306.4 & & 0.030 & & 1.15 \\
\hline American shad & 6.86 & 205.8 & 0.051 & & -0.031 & 0.98 \\
\hline Silver hake-northern & 3.58 & 143.7 & & 0.016 & & \\
\hline Silver hake-southern & 0.57 & -407.7 & & & & -0.69 \\
\hline Atlantic cod-GOM & -0.83 & & -0.0081 & 0.077 & & 0.50 \\
\hline Atlantic cod-GB & 1.48 & -454.5 & & & & \\
\hline \multicolumn{7}{|l|}{ Haddock-GOM } \\
\hline Haddock-GB & & -246.3 & & & & \\
\hline Pollock & & -281.1 & -0.0066 & 0.040 & 0.024 & 1.36 \\
\hline White hake & 2.10 & -279.8 & & 0.033 & & 0.85 \\
\hline Red hake-northern & 0.61 & 161.5 & & 0.027 & & \\
\hline Red hake-southern & 5.52 & -330.5 & & & & 0.41 \\
\hline Spotted hake & 3.44 & 503.6 & 0.020 & & & -0.46 \\
\hline Cusk & & -177.5 & -0.031 & 0.023 & & 0.77 \\
\hline Atlantic halibut & 2.57 & & & 0.022 & & 1.05 \\
\hline American plaice & & -231.8 & -0.0051 & & & 0.53 \\
\hline Summer flounder & & & 0.029 & & & \\
\hline Fourspot flounder & & & 0.042 & & & \\
\hline Yellowtail flounder-northern & & 81.8 & & & & 0.44 \\
\hline Yellowtail flounder-southern & 4.32 & -496.0 & -0.019 & 0.044 & & \\
\hline Winter flounder-northern & -3.82 & 110.8 & & & & 0.39 \\
\hline Winter flounder-southern & 1.55 & & & 0.035 & & \\
\hline Windowpane flounder & 3.81 & & & & & 0.31 \\
\hline Atlantic mackerel & & 250.2 & & & & -1.38 \\
\hline Acadian redfish & & -159.8 & -0.0063 & 0.037 & & \\
\hline Blackbelly rosefish & 8.53 & & 0.017 & & -0.04 & \\
\hline Longhorn sculpin & 1.87 & & & & & \\
\hline Goosefish & 1.61 & & & & & 1.19 \\
\hline Sea raven & & & & 0.021 & & \\
\hline Atlantic wolffish & & -188.8 & & 0.025 & & 0.51 \\
\hline Ocean pout & 0.93 & & & 0.025 & & 0.51 \\
\hline
\end{tabular}

found at increasingly greater depth, but had no apparent shifts in the center of biomass. These fishes are generally found in the GOM. There were several stocks that were found at increasingly deeper stations, but that did not produce statistically significant linear increases in depth of occurrence. The southern stocks of red hake and silver hake may have shifted to deeper water in more recent years (Fig. S1), but this was not detected by linear regression (Table 3). Six stocks were found at increasingly shallow depths, and all of these species have increased in abundance and/or exhibited a range expansion over the time series (Table 3, Fig. S2 in the Electronic Supplement, available at www. int-res.com/articles/suppl/m393p111_app.pdf).

Only 4 of the 36 stocks examined showed a statistically significant change in mean temperature over time (Table 3). Of these, American shad and blackbelly rosefish exhibited statistically significant decreases in mean temperature concomitant with a poleward shift in the mean center of biomass. However, Atlantic herring and pollock showed no significant poleward movement, but changes in temperature of occurrence and area occupied. The range in mean temperature of occurrence for all other stocks remained within a 2 to $5^{\circ} \mathrm{C}$ temperature range over the $40 \mathrm{yr}$ examined, despite observed spring BTs between 0 and $20^{\circ} \mathrm{C}$.

Species' range or area occupied in these fish stocks can be predicted by abundance (Fig. S3 in the Electronic Supplement, available at www.int-res.com/ articles/suppl/m393p111_app.pdf). The relationship between area occupied and abundance is very strong for most stocks, but varies among all stocks. There does not appear to be a strong relationship for some stocks such as longhorn sculpin, sea raven, winter flounder-southern and American plaice in which the range of abundance over the time series is low. 


\section{Multivariate analyses}

The factors associated with these shifts in distribution were examined using CanCorr analysis. There were significant linear relationships between distributional measures (response variables) and explanatory factors (environmental variables and biomass) for all species. The first canonical variate was significant in all stocks $(\mathrm{p}<0.05)$. The second canonical variate was significant in 26 of the 36 stocks ( $p<0.05$ ), and, cumulatively, the first 2 canonical variates explained at least $83 \%$ of the variability in each stock. The advantage of CanCorr is that correlations between multiple response and multiple explanatory variables can be examined, and correlations within the response and explanatory variables are also elucidated. These correlations can be visualized in biplots of the loadings (correlations between the variables and their respective canonical variates).

Biplots of the loadings are shown only for 12 stocks in which the first 2 canonical variates were statistically significant and the cumulative percentage of the variance explained was $>88 \%$ (Figs. 5 to 7). In most stocks, area was closely loaded with BIOMASS (Figs. 5 to 7), which would be expected from the tight relationships described between area and abundance (Fig. S3). BT and SST were loaded similarly, but were always loaded orthogonally to AMO, emphasizing the different scales at which these environmental metrics operate.

Three broad patterns emerged from the biplots depending on the biogeography of the stock. Stocks at the southern extent of their range responded negatively to an increase in the AMO index (Fig. 5). Stocks at the northern end of their range responded positively to an increase in the AMO index (Fig. 6). Stocks confined to the GOM did not shift their center of biomass in response to warming, but shifted their depth distribution (Fig. 7). In stocks at the southern limit of their range, distance is loaded similarly to AMO and opposite to both BIOMASS and area (Fig. 5). This can be interpreted as the BIOMASS and area of the stock decreasing, while the center of biomass (distance) moves increasingly poleward as warming increases. In southern stocks, warming, as indicated by the $\mathrm{AMO}$, is favorable and leads to similar loadings in AMO, BIOMASS, area, and distance (Fig. 6). These loadings can be interpreted as an increase in biomass, area occupied, and a poleward shift in distribution in response to warming. Stocks limited to the GOM appear to respond to warming by increasing their depth preference (Fig. 7). The AMO is loaded similarly to depth of occurrence and opposite to BIOMASS and area, which can be interpreted as a decrease in stock size, area occupied, and a shift to deeper depths as warming increases. Some species that had range expansion tend to have significant changes in mean temperature (Table 1), and BT and mean temperature of occurrence are not as highly correlated in CanCorr (Fig. 6). However, those species in which temperature of occurrence was highly correlated with BT were also experiencing range contraction and reductions in biomass (Fig. 5).

A striking aspect of these results is the difference in response between species located in the southern extent of the survey as compared to those that are re-
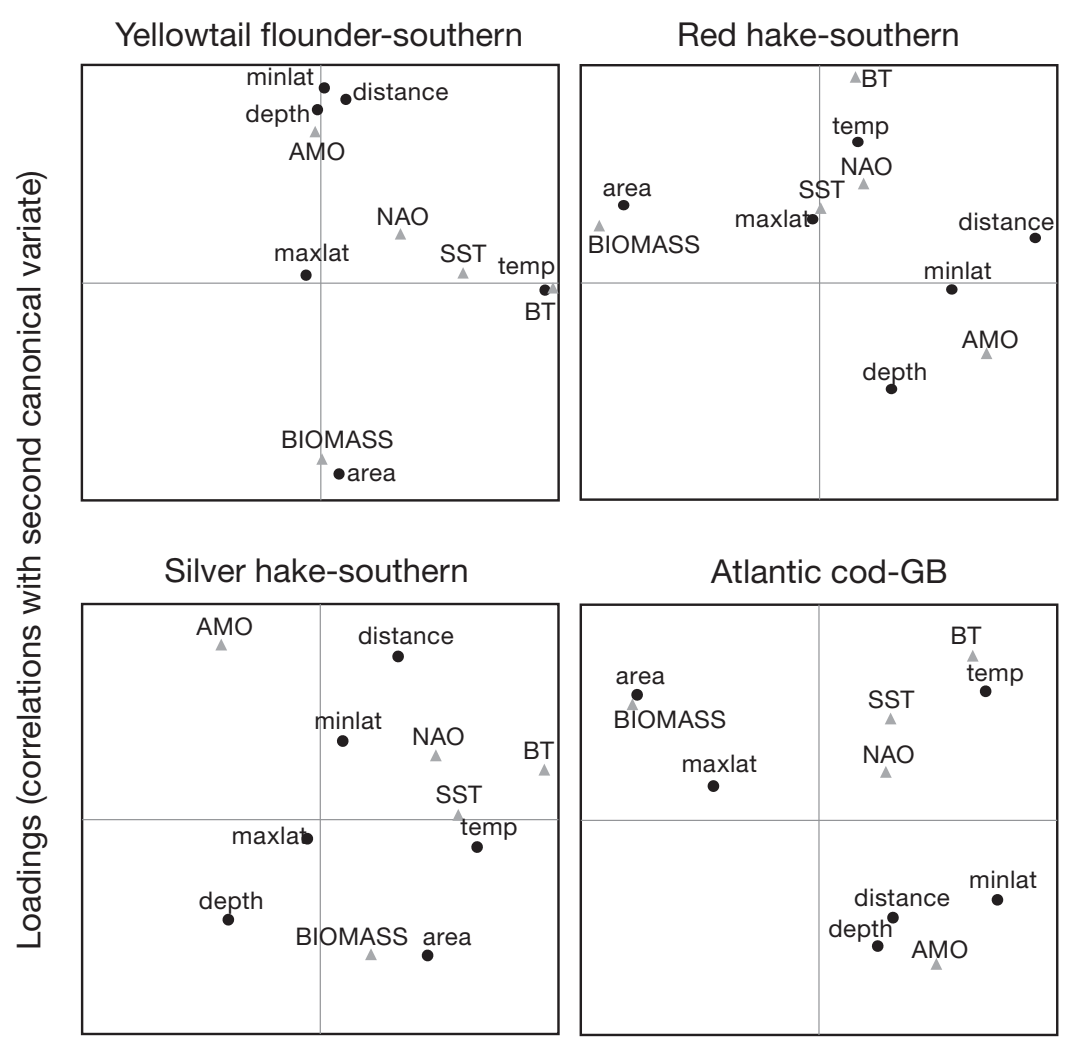

Loadings (correlations with first canonical variate)

Fig. 5. Loadings (correlations with canonical variates) for the first 2 canonical axes for the explanatory variables (triangles) and response variables (circles) for 4 representative stocks responding unfavorably to warming. Unfavorable responses include a decrease in population size (BIOMASS), decrease in area occupied (area), and a poleward shift in the center of biomass (distance) with an increase in Atlantic Multidecadal Oscillation (AMO) index. Scales for both the $x$ - and $y$-axes range from -1 to 1. NAO: North Atlantic Oscillation; SST: sea surface temperature; BT: bottom temperature; depth: depth of occurrence; maxlat and minlat: maximum and minimum latitude, respectively 


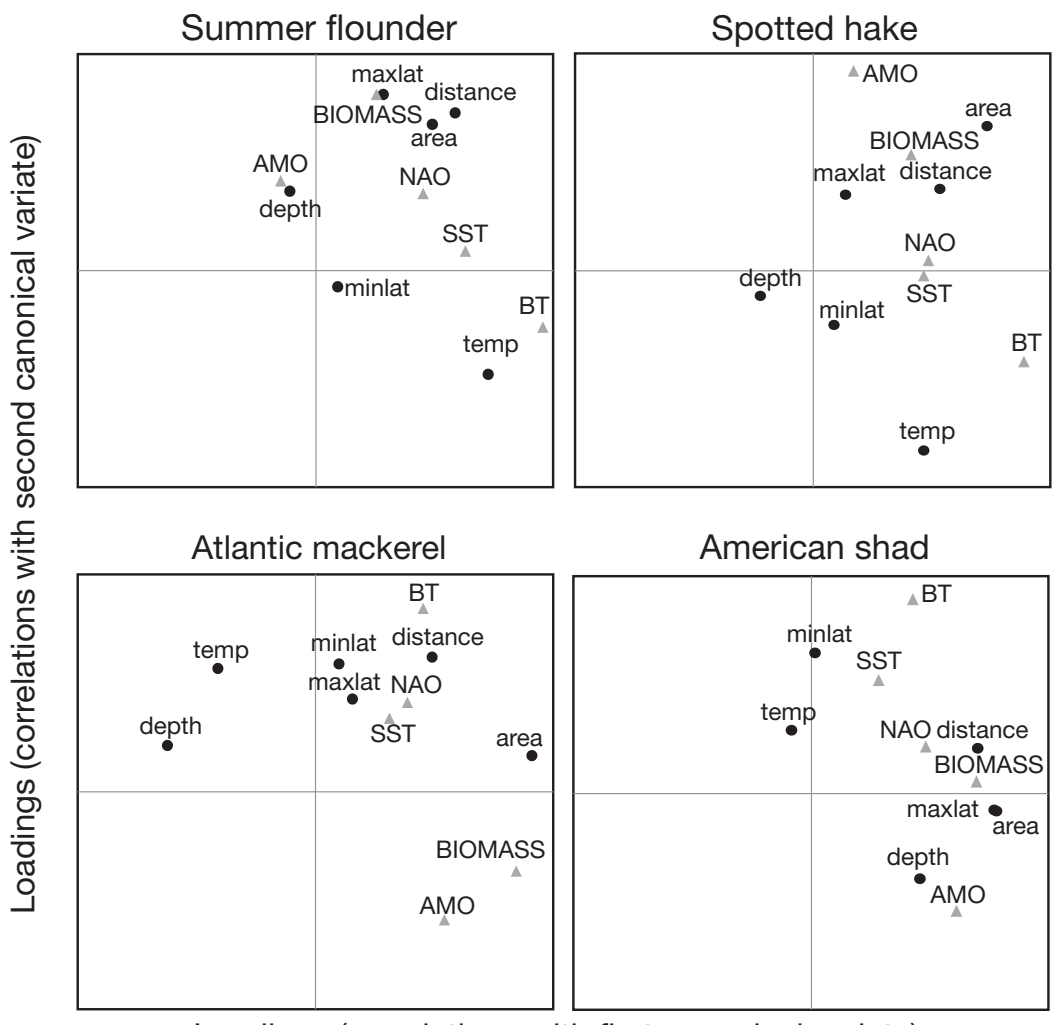

Loadings (correlations with first canonical variate)

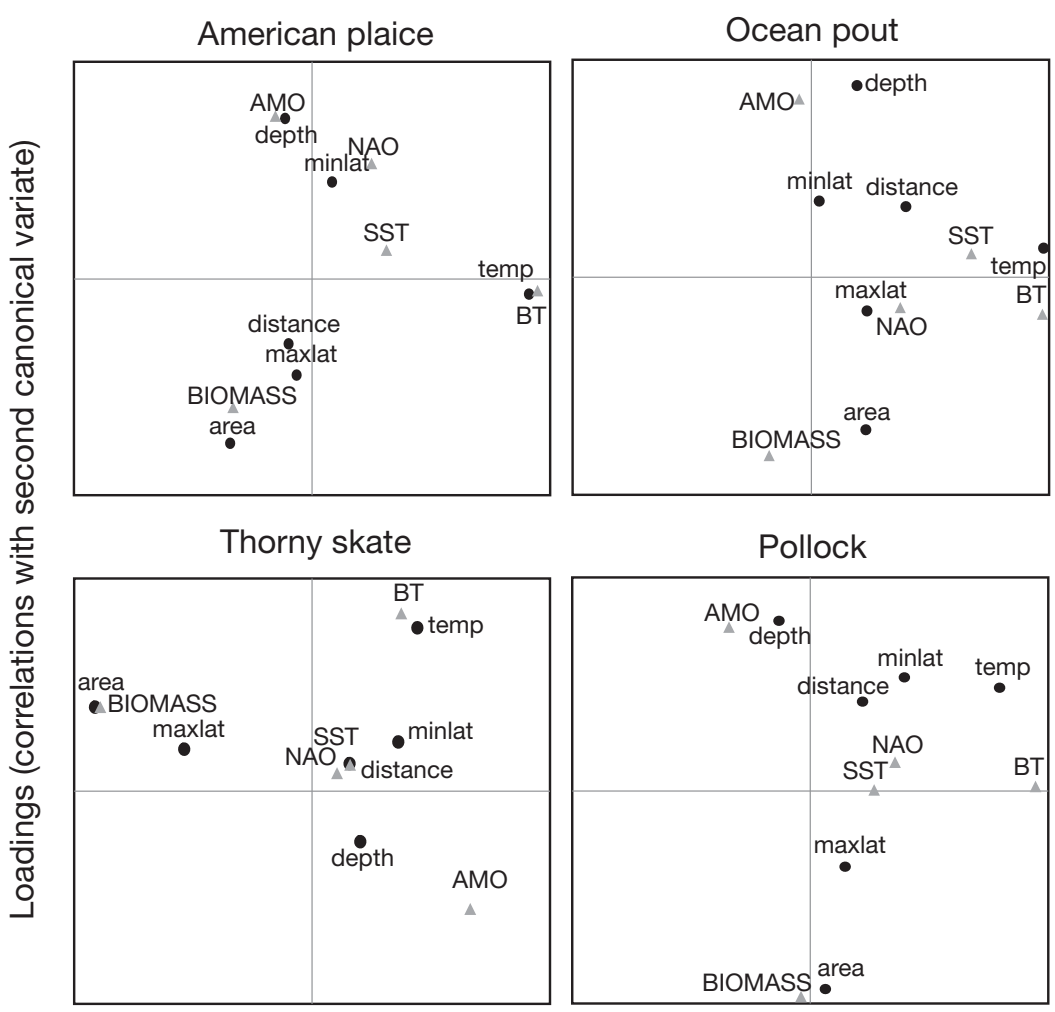

Loadings (correlations with first canonical variate)
Fig. 6. Loadings (correlations with canonical variates) for the first 2 canonical axes for the explanatory variables (triangles) and response variables (circles) for 4 representative stocks responding favorably to warming. Favorable responses include an increase in population size (BIOMASS), increase in area occupied (area), and a poleward shift in the center of biomass (distance) with an increase in Atlantic Multidecadal Oscillation (AMO) index. Scales for both the $x$ - and $y$-axes range from -1 to 1 . Other abbreviations as in Fig. 5

stricted to the GOM or northern extent of the survey. To illustrate this difference, maps of red hake distribution were created in 5 yr time blocks, because this species occurs both in the GOM (red hake-northern) and SNEGB (red hake-southern) regions. Red hake was chosen because it was fished heavily in both ecoregions until the mid-1970s, after which fishing pressure became low and was below $F_{\mathrm{MSY}}$. The distribution of red hake-southern has changed much more noticeably than the red hake-northern stock (Fig. 8). From the 1970s and into the late 1980s, there were many high-density areas of red hake in both the northern and southern stocks. There were even high densities of fish located south of Long Island Sound in the MAB region. The statistical findings that the center of biomass of the southern red hake stock shifted while its range contracted are corroborated by these maps. These maps also support the statistical findings that the northern red hake stock did shift poleward in the GOM, but this shift was of much smaller magnitude than the poleward shift in the southern stock of red hake. The movements of red hake mirror the spatial pattern in warming observed along the NE United

Fig. 7. Loadings (correlations with canonical variates) for the first 2 canonical axes for the explanatory variables (triangles) and response variables (circles) for 4 stocks restricted to the Gulf of Maine responding unfavorably to warming by changing depth distribution. Scales for both the $x$ - and $y$ axes range from -1 to 1 . Other abbreviations as in Fig. 5 

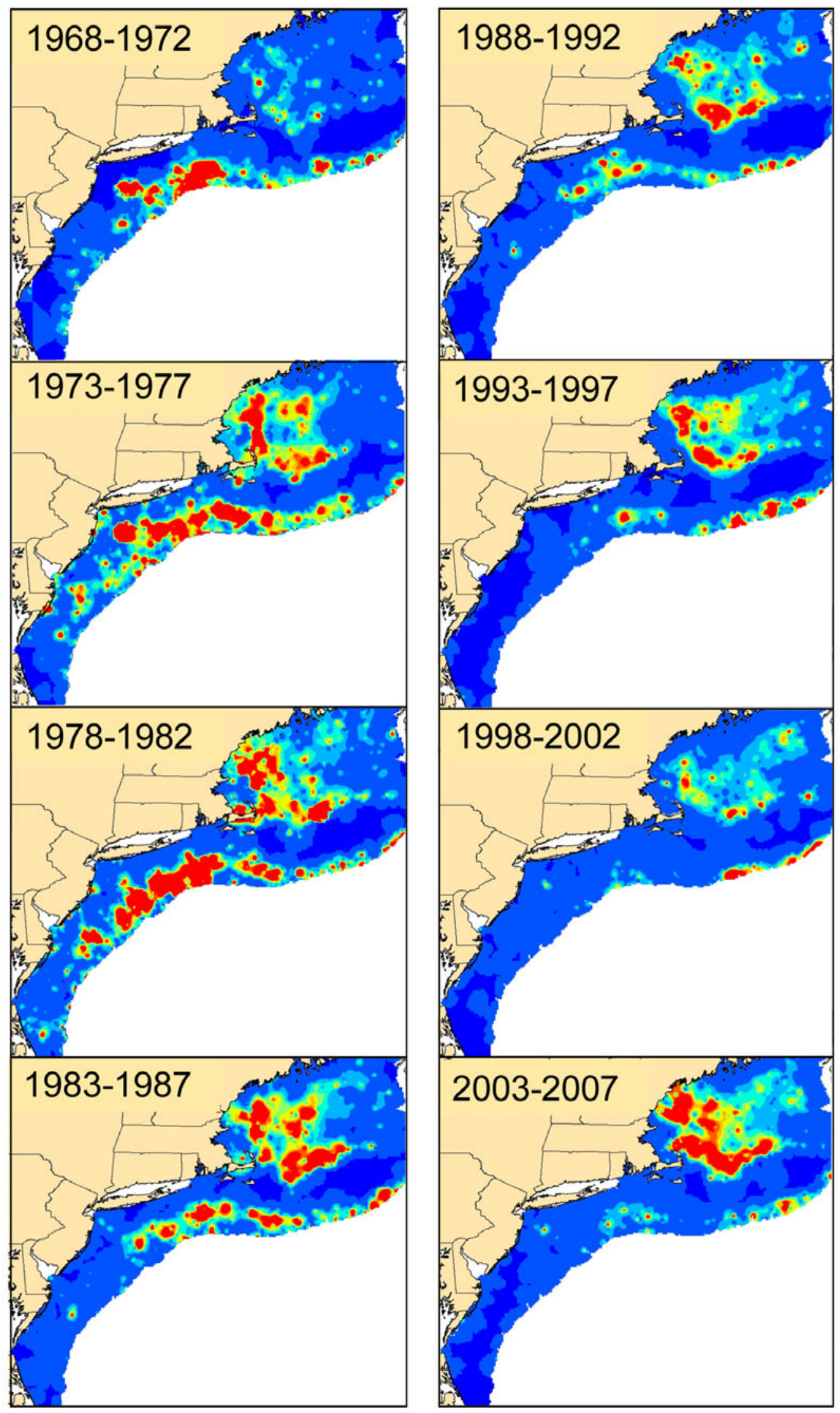

\section{Biomass \\ (kg tow-1)}

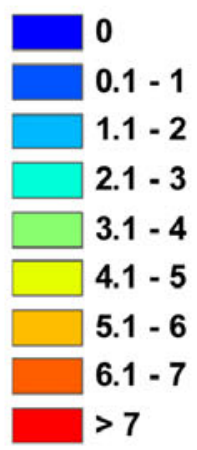

Fig. 8. Smoothed maps of red hake spatial distribution (northern and southern stocks combined) in 5 yr time blocks using inverse distance weighting. Units of biomass are in kilograms per tow 
States continental shelf, as shown analogously in $5 \mathrm{yr}$ time blocks (Figs. $2 \&$ 8). The distributional changes of red hake reflect those of species with similar stock structure, but also species that are traditionally found in SNE and the MAB as compared to those that are restricted to the GOM.

Distributional responses were different depending on the biogeography of the species (Fig. 9). The poleward shift in the center of biomass was much larger in the southern stocks than the northern stocks (Fig. 9a). Southern stocks also exhibited shifts to deeper depths, but of a

a) Poleward shift (distance)

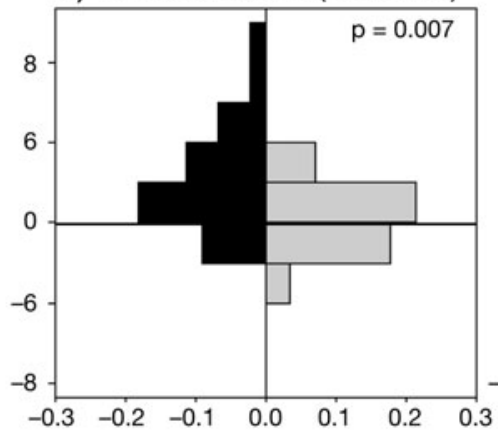

b) Mean depth

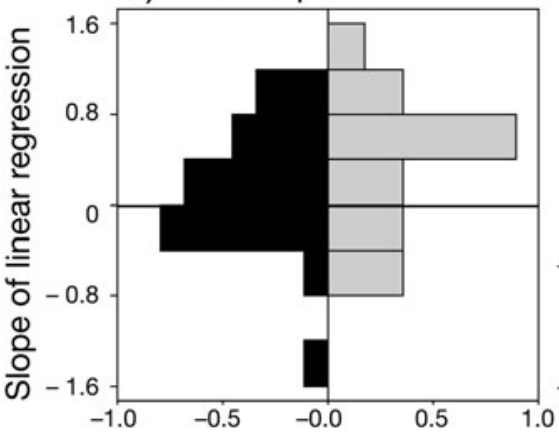

c) Mean temperature

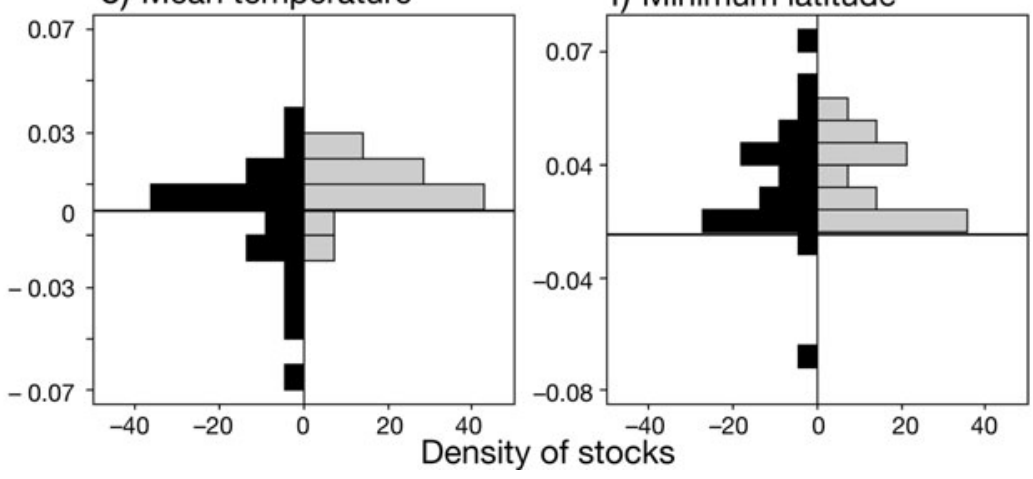

Fig. 9. Histograms comparing distributional responses for northern (gray) and southern (black) stocks in (a) distance shifted poleward, (b) mean depth, (c) mean temperature, (d) area occupied, (e) maximum latitude, and (f) minimum latitude. Significant differences detected with a Mann-Whitney $U$-test between species found in the 2 ecoregions are indicated by $p$-values smaller magnitude compared to northern stocks (Fig. 9b). The temperature of occurrence did not change over time for most stocks, as indicated by the majority of observations being centered around zero (Fig. 9c). There was also little difference between the northern stocks and southern stocks in area occupied, but it does appear that, in general, northern stocks were more likely to experience a range contraction (Fig. 9d). Maximum latitude increased for more of the southern stocks (Fig. 9e) and minimum latitude increased for all stocks except for 2 southern stocks (Fig. 9f). There was a significant difference between the distributions of slopes in the 2 ecoregions for only 2 distribution metrics, distance moved poleward and maximum latitude (Mann-Whitney; Fig. 9).

In summary, 24 of the 36 stocks displayed statistically significant changes consistent with warming, as indicated by a poleward shift in the center of biomass, an increase in mean depth of occurrence, and/or an increase in mean temperature. Additionally, fourspot flounder and summer flounder show weak indications of distributional changes consistent with warming. Ten stocks had distributional changes that were possibly nonlinear or were inconsistent with a response to warming.

\section{DISCUSSION}

We have demonstrated clear shifts in spatial distribution for the majority of fish stocks that we examined on the NE United States continental shelf. In 24 of the 36 stocks, we detected statistically significant changes associated with large-scale warming. Poleward shifts in the center of biomass and increases in the depth distribution were consistent with the predicted responses to climate change that previous studies have documented in many ecosystems (Southward et al. 1995, Parmesan \& Yohe 2003, Rosenzweig et al. 2008 for reviews) and in marine fishes (Holbrook et al. 1997, Perry et al. 2005, Dulvy et al. 2008). The long-term changes in distribution that we detected were appropriately correlated with large-scale warming and climatic conditions, specifically the AMO, and were not associated with measures of annual temperature fluctu- 
ations (BT or SST) as previous studies have documented (Taylor et al. 1957, Murawski 1993, Rose 2005). Long-term trends in distribution were not correlated with mean spring BT, indicating that fish populations have shifted their distribution in response to a consistent warm temperature regime over a large temporal and spatial scale. A warmer temperature regime, as indicated by the $\mathrm{AMO}$, is supported by other studies in the region showing that the range in annual water temperatures has increased; winter temperatures have remained fairly constant, while summer temperatures have increased (Friedland \& Hare 2007). Additionally, annual surface temperatures have increased over time, while annual BTs have not (Mountain 2003). The association of changes in distribution with large-scale climate variables rather than annual temperature variability suggests that these shifts are likely to persist, as large-scale circulation and temperature changes continue as a result of global climate change (IPCC 2007 , Solomon et al. 2009). The lack of change in the mean temperature of occurrence for most species indicates that species shifted their distribution to remain within their preferred temperature range.

The present study provides an empirical test of Murawski's (1993) hypothesized distributional shifts in NE United States fish stocks according to a warming scenario. Murawski (1993) predicted that warm-water migratory species, such as Atlantic herring and mackerel, would be most sensitive to warming, while shallow-water sedentary fishes would exhibit smaller changes in distribution on the NE United States continental shelf. However, we have shown that distributional changes were evident for species across many families, life histories, habitat preferences, and historical fishing pressures. Even species that Murawski (1993) termed 'shallow-water sedentary' such as yellowtail flounder, winter flounder, windowpane, and longhorn sculpin showed poleward distributional shifts. Additionally, we provide preliminary evidence that the range of summer flounder, also termed a 'sedentary' species, has expanded over time, that its abundance increased, and that the center of biomass was displaced poleward within the survey area. Murawski (1993) identified species such as fourspot flounder, goosefish, halibut, cod, alewife, and silver hake that had low variance in their mean latitude, depth, and temperature of occurrence. The present analysis indicates that these species exhibited some of the largest shifts in distribution concomitant with a persistent warming trend along the NE United States continental shelf. Consistent with Murawski's (1993) identification of life-history adaptations to annual temperature change, warm-water migratory species alter their geographical distribution annually, as indicated by the close association between annual mean BT and the mean temperature of occurrence. However, more sedentary species do not adapt as quickly to interannual temperature differences and, thus, display larger distributional changes as a result of a consistent warm temperature regime.

Murawski (1993) also identified a deep-water sedentary group that was, in general, restricted to the GOM. While temperatures in the deep waters of the GOM may not experience fluctuations in temperature as large as the shallower parts of the NE United States continental shelf, we did see range contraction in many of these species (white hake, pollock, cusk, American plaice, Acadian redfish, and Atlantic wolffish) and an increase in the depth of occurrence (Atlantic codGOM, pollock, cusk, Atlantic halibut, and ocean pout). The presence of distributional changes even in areas where a response was not expected heightens concerns over how species will respond if warming trends continue. Our analysis supports Murawski's (1993) contention that deep-water sedentary fish, particularly those in the GOM, may not adjust their spatial distribution in response to warming, but may experience greater changes in growth, reproduction, and recruitment than those fish that have shifted their distribution.

Distributional responses were most pronounced in southern species for which their centers of biomass were historically in SNE and the MAB, as illustrated by the comparison between the southern and northern stocks of red hake. The center of biomass for most of the southern stocks shifted to the northwest over the time series. Northern stocks traditionally found in the GOM, including the northern red hake stock, shifted poleward only slightly, if at all. Thus, the bathymetry and geography of the survey area was important in detecting changes in spatial distribution. Spatial distribution of temperature indicates a lack of suitable cool deep-water habitats to which GOM stocks could move. If fish shifted directly poleward or in a northwesterly direction from their historical GOM habitat, the shallow waters of the Bay of Fundy and Scotian shelf would be suboptimal for many of the cold deep-water fish of the GOM. Although stocks that were restricted to the GOM generally did not exhibit poleward shifts in their centers of biomass, they exhibited increases in mean depth of occurrence and temperature of occurrence, as was the case in cusk and pollock. Although temperatures in the GOM are generally more stable than in other regions of the present study, temperature has increased slightly in the GOM over the survey time series (Friedland \& Hare 2007) and there has been a recent decrease in salinity and increase in stratification (Drinkwater et al. 2009) to which GOM organisms will have to adapt.

CanCorr effectively separated out the effects of warming from changes in biomass for most of the stocks 
examined. The overwhelming response of these stocks to warming was a poleward shift in the center of biomass, and the response to an increase in biomass was a range expansion. Conversely, a range contraction was associated with a decrease in biomass more than with a change in temperature. CanCorr analysis also emphasized that distributional responses involve the complex interactions between fluctuations in biomass and environmental forcing. Consistent with hypothesized spatial shifts induced by warming (Hughes 2000, Walther et al. 2002, Parmesan \& Yohe 2003, Root et al. 2003), many southern species shifted their range northward, but they also experienced more favorable conditions for growth and recruitment, resulting in abundance increases and range expansion (Hare \& Able 2007). More northerly species made only slight shifts north, but their ranges contracted, or they were found at increasingly greater depths.

Previous studies have identified remarkably consistent fish communities that have persisted over a long time along the NW Atlantic coast (Overholtz \& Tyler 1985, Gabriel 1992, Mahon et al. 1998). However, Gabriel (1992) found that the boundaries of southern $\mathrm{MAB}$ and $\mathrm{GB}$ species assemblages were the most variable and seemed to be modified by annual differences in temperature. Our analysis supports this finding, and, while we only analyzed 36 stocks, we suspect an analysis of the finfish community would indicate a poleward shift in the southern boundary of the MAB and GB fish community, as has been found previously along the NW Atlantic coast (Gabriel 1992, Mahon et al. 1998). We have shown here that fish species have shifted their distributions at different rates. Thus, the way in which distributional shifts have changed community structure and species interactions should be evaluated.

Many fish species undergo ontogenetic shifts in depth distribution (MacPherson \& Duarte 1991, Methratta \& Link 2007, Labropoulou \& Damalas 2008), a well-documented relationship in the ecological literature termed 'Heincke's Law' (Heincke 1913). Depth distribution might be expected to change as many heavily fished stocks experience fluctuations in abundance as well as in size structure. We did not investigate the effects of size structure on distributional responses, but, if age structure were to be the main cause of distributional changes, we would expect heavily fished stocks with truncated age structure to be found at increasingly shallower depths and recovering stocks with expanding age structure to be found at increasingly deeper depths. However, no stock found at increasingly deeper stations could be explained by an increase in abundance. Only silver hake-northern was found at increasingly shallow depths, which could be explained by a decrease in abundance over the course of the time series and a recent stock structure composed of more
Age 1 fish and few fish older than Age 3 (NEFSC 2001). Additionally, in the CanCorr analysis biomass was never loaded similarly with depth of occurrence.

Distributional shifts may be obscured by changes in biomass, especially if species are found frequently outside the survey area or if their distribution is limited by bathymetry and habitat availability (Spencer 2008). For example, we observed no significant distributional shifts in haddock found in either the GOM or GB/SNE ecoregion. The abundance of haddock has increased considerably since its lowest biomass levels in the 1990s. Therefore, shifts in the center of biomass by this stock might be masked by its recent increase in population size and may not be detected by linear statistical methods. Similarly, we saw southward shifts in the center of biomass with range expansion in winter skate, spiny dogfish, and, to a lesser extent, little skate. All 3 of these elasmobranch species experienced significant increases in abundance in the 1990s, but the ranges of these species extend beyond the boundaries of our survey, making trends in spatial distribution difficult to interpret presently. In the future, it will be important to compare surveys from adjacent areas to accurately describe distributional changes in fish stocks and to accurately assess their population sizes (Blanchard et al. 2008).

We found a tight relationship between abundance and the area occupied in each species, and this finding was corroborated by the similar loadings between biomass and area in the CanCorr. This relationship is well documented in the ecological literature (Brown 1984, MacCall 1990, Frank \& Shackell 2001), so these tight relationships are not surprising. By illustrating this tight relationship in all 36 stocks examined, we emphasize that changes in abundance are expressed in the area occupied by each species and that changes in the center of biomass are a response to changes in environmental conditions. Most of the species in the present study have been subjected to the direct or indirect effects of fishing. However, spotted hake, blackbelly rosefish, sea raven, and longhorn sculpin have not been subjected to a direct fishery, and all indicated poleward shifts in their distribution suggesting further that these shifts are in response to climatic events and not to fishing practices or changes in abundance.

A strength of this work is that we have shown distributional responses consistent with warming in multiple stocks with a variety of life-history characteristics and habitat preferences; this provides a kind of replicated test of our hypothesis that recent warming has caused shifts in spatial distribution. These shifts were most highly correlated with the AMO, but the mechanisms by which changes in distribution occur are still unknown. In the NE United States, positive AMO phases are associated with warmer land and ocean tempera- 
tures, increases in rainfall and river flow in the GOM region, and decreases in rainfall and river flow in the SNE and MAB areas (Enfield et al. 2001, Sutton \& Hodson 2007). Both temperature and river flow have been shown to influence fish distribution and recruitment dynamics (Hare \& Able 2007, Wood \& Austin 2009, Hare et al. in press). The AMO has also been associated with basin-scale circulation changes, changes in salinity and temperature, and bio-geographical shifts in plankton, fish, and whales in the NE Atlantic (Hatun et al. 2005, Beaugrand et al. 2009). In contrast, the way in which the AMO affects ecosystems of the NW Atlantic is poorly understood. However, it has been hypothesized that synchronous dynamics, but opposite in sign, in functionally similar fish stocks in the NE and NW Atlantic are connected by unknown mechanisms that influence the regions in opposite ways (Megrey et al. 2009). Thus, the AMO may be an index of oceanic circulation that synchronously influences both sides of the North Atlantic and causes poleward shifts in spatial distribution of marine organisms, now documented in both eastern and western Atlantic ecosystems.

The AMO could influence fish distribution in several ways, all centering on the thermal environments experienced by these fishes. We propose 4 potential mechanisms and suggest ways in which to test these hypotheses. (1) Large-scale changes in temperature might induce directed movement of fish from warm waters to cooler waters within their preferred temperature range that are either deeper or poleward of their historical distribution. While directed movement to more favorable habitat occurs in many species, it probably occurs at a smaller spatial scale than the substantial shifts in distribution that we observed. Large movements on the order of 100 s of kilometers and reductions in the species' range on the order of $20000 \mathrm{~km}^{2}$ are probably not the result of directed movement alone. Large-scale tagging experiments and continued temporally and spatially intensive sampling over multiple years would be needed to document directed movement.

(2) Migration patterns and timing may change in response to increases in temperature that are better represented by the AMO index than by snapshots of BT at the time of our survey. Many of the fishes in the present study migrate up and down the east coast of the United States in response to seasonal changes in temperature. However, as the temperature regime warms, cold-water species may not migrate as far south in the winter; thus, we would observe a poleward shift in distribution when the species are sampled in the spring. Similarly, warm-water species may be able to move poleward and expand their range as summers are consistently warmer. Large-scale tagging studies might elucidate such a mechanism, but intensive summer- and winter-time sampling might also capture changes in the northern and southern limits to which stocks migrate.

(3) A third mechanism resulting in large population shifts in distribution is that large-scale changes in temperature and circulation represented by the AMO may increase mortality at the southern extent of a species' range, particularly in early life stages. While hatching at lethal temperatures would directly increase the mortality of eggs and larvae, reduced growth rate at suboptimal temperatures may indirectly increase mortality via an increase in predation and starvation (Houde 1987, 1989). Furthermore, changes in circulation may transport eggs and larvae to suboptimal nursery habitat, and alterations in the phenology of oceanographic processes, such as stratification, may also have an impact on the recruitment success of these fishes. Mortality at the southern extent of a species' range, where temperature is most likely to be above the species' preferred temperature, may explain the shift in spatial distribution and would be reflected in stock-recruitment relationships. An analysis of stock-recruitment dynamics of meta-populations would clarify whether there are differences in mortality and recruitment among metapopulations of the same species. We hypothesize that stocks at the southern extent of their range have experienced unfavorable environmental conditions for recruitment during the recent positive AMO phase, leading to the local extirpation of many of these stocks at the southern range limit. Conversely, stocks at the northern extent of a species' range may have experienced favorable conditions for recruitment, leading to an increase in abundance and range expansion.

(4) From an ecosystem perspective, changes in temperature and salinity represented by the AMO may cause changes in the phytoplankton or zooplankton community, the effects of which may transfer through the food web. Fish movement, migration, and recruitment might all be directly influenced by abiotic factors such as temperature, salinity, and circulation patterns, but they may also be influenced indirectly by changes in the distribution and abundance of lower trophic level organisms. There may be some directed movement by fish to follow prey. In addition, changes in abundance, distribution, and composition of the plankton community may allow high recruitments and population growth in some species and the opposite response in others. A holistic understanding of ecosystem functioning would not only explain the shifts in fish distribution that we have documented, but may elucidate a positive feedback mechanism that explains why we have observed shifts on the order of 1 to $8 \mathrm{~km} \mathrm{yr}^{-1}$, similar to those in other studies on marine fish (Perry et al. 2005, Mueter \& Litzow 2008). For comparision, the average shift in terrestrial ecosystems is about $0.61 \mathrm{~km} \mathrm{yr}^{-1}$ (Parmesan \& Yohe 2003). 
We examined the role of population abundance, but were unable to directly examine the role of fishing in distributional shifts. Fishing pressure may intensify the effects of climate change (Hsieh et al. 2008, Planque et al. in press), especially at the southern extent of the species' range in this region. Commercially important species such as red hake, Atlantic cod, yellowtail flounder, alewife, and American shad have historically experienced intense fishing pressure, and all of these stocks are at record low levels, particularly at the southern limit of their range. For many of these species, management has reduced fishing mortality, yet the southern stocks have not been able to recover to historic population sizes or to support viable fisheries. We hypothesize that these species have failed to fully recover from intense fishing at the southern extent of their range, in part because of warming along the continental shelf. The observations that stock size has decreased and the center of biomass has shifted poleward in some southern stocks of these species, while stock size has increased in northern stocks of these species suggests that there may be movement of fish from the southern stock into the northern stock. This may be the case with the red hake, silver hake, yellowtail flounder, and winter flounder and has important management implications. The effects of climate and/or changes in distribution should be incorporated into stock assessments and management scenarios. Incorporating a broader set of considerations into stock assessments by using an index of warming such as the AMO might improve stock-recruitment relationships, explain the lack of recovery to date for some stocks, and provide more refined management advice.

Acknowledgements. This work was supported by a NOAA NMFS Fisheries and the Environment (FATE) grant. We thank all those who participated in the NEFSC bottom trawl survey. We thank M. Fogarty, K. Friedland, D. Hart, L. Jacobson, C. Keith, R. McBride, and M. Taylor for thoughtful comments on this work.

\section{LITERATURE CITED}

Azarovitz TR (1981) A brief historical review of the Woods Hole Laboratory trawl survey time series. In: Doubleday WG, Rivard D (eds) Bottom trawl surveys. Can Spec Publ Fish Aquat Sci 58:62-67

Beaugrand G (2004) The North Sea regime shift: evidence, causes, mechanisms and consequences. In: Regime shifts in the ocean: reconciling observations and theory. Prog Oceanogr 60:245-262

Beaugrand G, Brander KM, Lindley JA, Souissi S, Reid PC (2003) Plankton effect on cod recruitment in the North Sea. Nature 426:661-664

Beaugrand G, Luczak C, Edwards M (2009) Rapid biogeographical plankton shifts in the North Atlantic Ocean. Glob Change Biol 15:1790-1803

Belkin IM (2009) Rapid warming of large marine ecosystems. Prog Oceanogr 81:207-213
Blanchard JL, Maxwell DL, Jennings S (2008) Power of monitoring surveys to detect abundance trends in depleted populations: the effects of density-dependent habitat use, patchiness, and climate change. ICES J Mar Sci 65:111-120

Brown JH (1984) On the relationship between abundance and distribution of species. Am Nat 124:255-279

Clark RA, Fox CJ, Viner D, Livermore M (2003) North Sea cod and climate change-modelling the effects of temperature on population dynamics. Glob Change Biol 9:1669-1680

Drinkwater KF (2005) The response of Atlantic cod (Gadus morhua) to future climate change. ICES J Mar Sci 62: $1327-1337$

Drinkwater KF, Belgrano A, Borja A, Conversi A and others (2003) The response of marine ecosystems to climate variability associated with the North Atlantic Oscillation. In: Hurrell J, Kushnir Y, Ottersen G, Visbeck M (eds) The North Atlantic Oscillation, climatic significance and environmental impact. Geophys Monogr 134:211-234

Drinkwater KF, Mueter F, Friedland KD, Taylor M, Hunt GL Jr, Hare J, Melle W (2009) Recent climate forcing and physical oceanographic changes in Northern Hemisphere regions: a review and comparison of four marine ecosystems. Prog Oceanogr 81:10-28

Dulvy NK, Rogers SI, Jenning S, Stelzenmuller V, Dye SR, Skjoldal HR (2008) Climate change and deepening of the North Sea fish assemblage: a biotic indicator of warming seas. J Appl Ecol 45:1029-1039

Enfield DB, Mestas-Nunez AM, Trimble PJ (2001) The Atlantic multidecadal oscillation and its relation to rainfall and river flows in the continental U.S. Geophys Res Lett 28:2077-2080

Fogarty MJ, Incze L, Hayhoe K, Mountain DG, Manning J (2007) Potential climate change impacts on Atlantic cod (Gadus morhua) off the northeastern USA. Mitig Adapt Strateg Glob Change 13:453-466

Frank KT, Shackell NL (2001) Area-dependent patterns of finfish diversity in a large marine ecosystem. Can J Fish Aquat Sci 58:1703-1707

> Frank KT, Perry RI, Drinkwater KF (1990) Predicted response of Northwest Atlantic invertebrate and fish stocks to $\mathrm{CO}_{2}$ induced climate change. Trans Am Fish Soc 119:353-365

Friedland KD, Hare JA (2007) Long-term trends and regime shifts in sea surface temperature on the continental shelf of the northeast United States. Cont Shelf Res 27:2313-2328

Gabriel WL (1992) Persistence of demersal fish assemblages between Cape Hatteras and Nova Scotia, Northwest Atlantic. J Northwest Atl Fish Sci 14:29-46

Gray ST, Graumlich LJ, Betancourt JL, Pederson GT (2004) A tree-ring based reconstruction of the Atlantic Multidecadal Oscillation since 1567 A.D. Geophys Res Lett 31: L12205, doi:10.1029/2004GL019932

Greene CH, Pershing AJ, Conversi A, Planque B and others (2003) Trans-Atlantic responses of Calanus finmarchicus populations to basin-scale forcing associated with the North Atlantic Oscillation. Achievements of the continuous plankton recorder survey and a vision for its future. Prog Oceanogr 58:301-312

Hare JA, Able KW (2007) Mechanistic links between climate and fisheries along the east coast of the United States: explaining population outbursts of Atlantic croaker (Micropogonias undulatus). Fish Oceanogr 16:31-45

Hare JA, Alexander M, Fogarty M, Williams E, Scott J (in press) Forecasting the dynamics of a coastal fishery species using a coupled climate-population model. Ecol Appl

Hatun $H$, Sando AB, Drange H, Hansen B, Valdimarsson H (2005) Influence of the Atlantic subpolar gyre on the thermohaline circulation. Science 309:1841-1844 
Heincke F (1913) Untersuchungen über die Scholle. General Bericht I. Schollenfischerei und Schonmaßregeln. Vorläufige Übersicht über die wichtigsten Ergebnisse des Berichts. Rapp P-V Reun Cons Int Explor Mer 16:1-70

> Holbrook SJ, Schmitt RJ, Stephens JS Jr (1997) Changes in an assemblage of temperate reef fishes associated with a climate shift. Ecol Appl 7:1299-1310

Houde ED (1987) Fish early life dynamics and recruitment variability. Am Fish Soc Symp 2:17-29

Houde ED (1989) Subtleties and episodes in the early life stages of fishes. J Fish Biol 35:29-38

> Hsieh CH, Reiss CS, Hewitt RP, Sugihara G (2008) Spatial analysis shows that fishing enhances the climatic sensitivity of marine fishes. Can J Fish Aquat Sci 65:947-961

Hughes L (2000) Biological consequences of global warming: is the signal already apparent? Trends Ecol Evol 15: $56-61$

Hurrell JW, Kushnir Y, Ottersen G, Visbeck M (2003) An overview of the North Atlantic Oscillation. In: The North Atlantic Oscillation: climatic significance and environmental impact. Geophys Monogr 134:1-35

IPCC (Intergovernmental Panel on Climate Change) (2007) Climate change 2007: synthesis report. Contribution of Working Groups I, II and III. In: Team CW, Pachauri RK, Reisinger A (eds) Fourth assessment report of the Intergovernmental Panel on Climate Change. IPCC, Geneva

Knutson TR, Delworth TL, Dixon KW, Held IM and others (2006) Assessment of the twentieth-century regional surface temperature trends using the GFDL CM2 coupled models. J Clim 19:1624-1651

Labropoulou M, Damalas D (2008) Bathymetric trends in distribution and size of demersal fish species in the North Aegean Sea. J Nat Hist 42:673-686

Levitus S, Antonov JI, Boyer TP, Stephens C (2000) Warming of the World Ocean. Science 287:2225-2229

Lindley JA, Reid PC, Brander KM (2003) Inverse relationship between cod recruitment in North Sea and young fish in the continuous plankton recorder surveys. Sci Mar 67:191-200

Lozier SM, Leadbetter S, Williams RG, Roussenov V, Reed MSC, Moore NJ (2008) The spatial pattern and mechanisms of heat-content change in the North Atlantic. Science 319:800-803

MacCall AD (1990) Dynamic geography of marine fish populations. Washington University Press, Seattle, WA

MacPherson E, Duarte CM (1991) Bathymetric trends in demersal fish size - Is there a general relationship? Mar Ecol Prog Ser 71:103-112

> Mahon R, Brown SK, Zwanenburg KCT, Atkinson DB and others (1998) Assemblages and biogeography of demersal fishes of the east coast of North America. Can J Fish Aquat Sci 55:1704-1738

McCarty JP (2001) Ecological consequences of recent climate change. Conserv Biol 15:320-331

Megrey BA, Hare JA, Stockhausen WT, Dommasnes A and others (2009) A cross-ecosystem comparison of spatial and temporal patterns of covariation in the recruitment of functionally analogous fish stocks. Prog Oceanogr 81:63-92

Methratta ET, Link JS (2007) Ontogenetic variation in habitat associations for four flatfish species in the Gulf of Maine-Georges Bank region. J Fish Biol 70:1669-1688

Mountain DG (2003) Variability in the properties of the shelf water in the Middle Atlantic Bight, 1977-1999. J Geophys Res 108:3014, doi:10.1029/2001JC001044

> Mueter FJ, Litzow MA (2008) Sea ice retreat alters the biogeography of the Bering Sea continental shelf. Ecol Appl 18:309-320

Editorial responsibility: William Peterson,

Newport, Oregon, USA
Murawski SA (1993) Climate change and marine fish distributions: forecasting from historical analogy. Trans Am Fish Soc 122:647-658

NEFSC (Northeast Fisheries Science Center) (2001) The 32nd northeast regional stock assessment workshop (32nd SAW). Ref. Doc. 01-04, NEFSC, Woods Hole, MA

> O'Brien CM, Fox CJ, Planque B, Casey J (2000) Climate variability and North Sea cod. Nature 404:142

Overholtz WJ, Tyler AV (1985) Longterm responses of demersal fish assemblages of George Bank. Fish Bull (Wash DC) 83:507-520

Parmesan C, Yohe G (2003) A globally coherent fingerprint of climate change impacts across natural systems. Nature 421:37-42

Perry AL, Low PJ, Ellis JR, Reynolds JD (2005) Climate change and distribution shifts in marine fishes. Science 308:1912-1915

Planque B, Fromentin JM, Cury P, Drinkwater KF, Jenning S, Perry RI, Kifani S (in press) How does fishing alter marine populations and ecosystems sensitivity to climate? J Mar Syst

Reid PC, Borges Md F, Svendsen E (2001) A regime shift in the North Sea circa 1988 linked to changes in the North Sea horse mackerel fishery. Fish Res 50:163-171

$>$ Root TL, Price JT, Hall KR, Schneider SH, Rosenzweig C, Pounds JA (2003) Fingerprints of global warming on wild animals and plants. Nature 421:57-60

Rose GA (2005) On distributional responses of North Atlantic fish to climate change. ICES J Mar Sci 62:1360-1374

Rosenzweig C, Karoly D, Vicarellu M, Neofotis P and others (2008) Attributing physical and biological impacts to anthropogenic climate change. Nature 453:353-358

Shuter BJ, Post JR (1990) Climate, population viability, and the zoogeography of temperate fishes. Trans Am Fish Soc 119:314-336

Smith TM, Reynolds RW (2004) Improved extended reconstruction of SST (1954-1997). J Clim 17:2466-2477

Solomon S, Plattner GK, Knutti R, Friedlingstein P (2009) Irreversible climate change due to carbon dioxide emissions. Proc Natl Acad Sci USA 106:1704-1709

> Southward AJ, Hawkins SJ, Burrows MT (1995) Seventy years' observations of changes in distribution and abundance of zooplankton and intertidal organisms in the western English Channel in relation to rising sea temperature. J Therm Biol 20:127-155

Spencer PD (2008) Density-independent and density-dependent factors affecting temporal changes in spatial distribution of eastern Bering Sea flatfish. Fish Oceanogr 17: $396-410$

Sutton RT, Hodson DLR (2005) Atlantic Ocean forcing of North American and European summer climate. Science 309:115-118

Sutton RT, Hodson DLR (2007) Climate response to basinscale warming and cooling of the North Atlantic Ocean. J Clim 20:891-907

Taylor CC, Bigelow HB, Graham HW (1957) Climate trends and the distribution of marine animals in New England. Fish Bull 57:293-345

The Mathworks (2008) Matlab 7.7.0. The Mathworks, Natick, MA

- Walther GR, Post E, Convey P, Menzel A and others (2002) Ecological responses to recent climate change. Nature 416:389-395

> Wood RJ, Austin HM (2009) Synchronous multidecadal fish recruitment patterns in Chesapeake Bay, USA. Can J Fish Aquat Sci 66:496-508 